\title{
The Effect of Local Apparatus Competence, Financial Reporting Compliance and Internal Control Environment on Fraud Prevention: The Role of Local Assistants as Moderation Variable
}

\author{
Saparman ${ }^{1}$, Ridwan ${ }^{1}$, Muhammad Din ${ }^{1, *}$, Jamaluddin ${ }^{1}$, Supriadi Laupe ${ }^{1}$, Mohammad \\ Iqbal $^{1}$, Betty $^{1}$
}

${ }^{1}$ Department of Accounting, Faculty of Economics and Business, Tadulako University, Palu, Indonesia

*Corresponding author: Muhammad Din, Email: didi.kaili83@gmail.com

\begin{abstract}
The aims of this research are to inspect and investigate the impact of the competence of village officials, compliance with financial reporting, and the internal control environment on fraud prevention and to test the effectiveness of the role of village assistants to strengthen or weaken. This research is the actors who manage the village funds taken from each village, namely the head, secretary and village treasurer, with a total of 327 respondents. Sampling using the perposive sampling method, namely sampling based on criteria. Methods of data analysis using the WarpPLS 7.0 program assistance technique. Results have demonstrated that the expertise of village officials, compliance with financial statements and the internal monitoring environment have had a substantial and partial impact on the fraud prevention in village fund administration, the efficacy of the position of village assistants has not improved the competence of village officials to deter fraud, the effectiveness of village assistants. Internal regulation of fraud prevention in the administration of village funds, the moderation variable in this analysis was listed as quasi-modersai because the effectiveness component has a direct effect on the prevention of fraud.
\end{abstract}

Keywords: Local Apparatus Competence, Financial Reporting Compliance, Internal Control Environment, Fraud Prevention, Effectiveness of The Role of Local Assistants

\section{INTRODUCTION}

Village funds are a form of real governmental programs for the community, village funds that are given by the Village Apparatus to process and allocate budgets according to deliberations arranged by village officials and involve several communities. Village funds are intended to improve the welfare of people in rural areas. However, there are still people who misuse the village funds for their personal interests. For example, cases of corruption misuse of village funds in the period January to September 2017 were 54 cases. This misappropriation of village funds has caused state losses from this case estimated at more than Rp1.4 billion. Meanwhile, in 2018 to March 2019, there were 22 more cases of the same. Cases of misappropriation of village funds in the last 3 years on average involved village officials, namely the village head, secretary, and treasurer[1]. This paper aims to determine the extent of the influence of village officials and village fund financial reports as well as internal environmental supervision and village assistants in reducing misuse of village funds in Toli-Toli-Sulawesi Regency, Indonesia.

\section{THEORETICAL VIEWS HYPHOTHESIS DEVELOPMENT}

AND

\subsection{Fraud Triangle Theory}

The New Fraud Triangle Model introduced by Kassem and Higson in their research aims to broaden the knowledge of external auditors about fraud and why it occurs and to explain the model. Despite presents a fraud model, Cressey's model also proposes a new fraud triangle model. The risk related to fraud should be considered by external auditors. This research also shows that all other fraud models should be considered as extensions of Cressey's fraud triangle model and integrated into one model including motivation, 
opportunity, integrity and capability. This model is also known as "The New Fraud Triagle Model" [2]. Fraud is a deviation or illegal act (Illegal Acts) which is done on purpose, for a specific purpose, for example cheating or misleading for personal or group gain unfairly, either directly or indirectly harming other parties

\subsection{The Influence of the Competence of Village Officials on The Prevention of Fraud in The Management of Village Funds}

Adequate apparatus competence in managing village finances, it is hoped that the economic and social objectives of village government can be achieved. Therefore, the participation of parties outside the village administration and the village consultative body, such as village leaders, religious leaders, farmers, village entrepreneurs, and other community representatives must work together and be involved in managing village funds. One of the research variables is influence apparatus competence in preventing fraud in the management of village funds $[\mathbf{3}, \mathbf{4}, \mathbf{5}, \mathbf{6}, \mathbf{7}]$. The Fraud Triangle has the view that with the competence of village officials, it will be able to overcome the problem of fraud in the process of managing village funds, namely the rationalization of both attitudes or characters. This illustrates that the character of a good village apparatus can be possessed and has an impact on fraud preventing in the village funds management. Based on this explanation, the following research hypothesis is proposed:

$\mathrm{H}_{1}$ : Apparatus competence has a positive effect on fraud prevention in the management of village funds.

\subsection{Effect of Financial Reporting Compliance on Fraud Prevention in Village Fund Management}

The Minister of Home Affairs of the Republic of Indonesia issued No. 113, 2014, which concern village financial management, regulates the principles of village financial management. This regulation consists of transparency, accountability, participatory \& orderly, and budget discipline. Transparency means that all access to information and decision-making processes are owned by the community, so compliance with financial reporting is one of the causes of fraud prevention. Financial reports aim to ensure the management of activities is known to the public. This is a form of responsibility, morally, technically, legally and administratively. Government financial management must actively involve the community from the planning stage to monitoring activities (participatory). Furthermore, budget order and discipline are reflected in consistency, on time, on quantity, and in compliance. When connected with the fraud triangle theory used in this study, there are four types of conditions that generally occur pressures that can lead to fraud include financial stability, external pressure, personal needs, and financial targets. If the village apparatus does not experience the pressure, the village apparatus will compile a financial report according to the allocation of village funds [7]. Based on this explanation, the following research hypothesis is proposed:

$\mathrm{H}_{2}$ : Compliance with reporting has a positive effect on fraud prevention in the management of village funds.

\subsection{The Influence of the Internal Control Environment On Fraud Prevention in The Management of Village Funds}

The third factor that affects the fraud prevention in village funds management is internal control. Environmental control is the earliest component in the internal control system. The committee of sponsoring of the treadway commission explains that environmental control consists of actions, policies, and procedures that reflect the attitudes of top management, directors and owners. They are the entity as a whole regarding internal control and their role to the entity. Increasing the moral ethics, responsibility in organizational management within the village government is a necessity. This internal influence can reduce the risk of misuse of village funds $[8,5,9]$. Based on this explanation, the following research hypothesis is proposed:

$\mathrm{H}_{3}$ : Internal control environment has a positive effect on fraud prevention in the management of village funds.

2.5. The Role of Village Assistants in Moderating the Influence of the Competence of Village Officials, Compliance with Financial Reporting and the Control Environment On Fraud Prevention in Managing Village Funds

Village assistance is to facilitate and assist the community in the village governance implementation, village development, community development and community's empowerment. Facilitation can be done in creative ways based on Law Number 6, 2014, which describe about the villages and all its implementing regulations. The formation of a village assistant consists of trained staf that will assist the central government in realizing the main objectives of village funds. Village assistants have the task of conveying regulatory changes, conducting training on village apparatus development, and supervising or controlling village development [10]. Based on this explanation, the following research hypothesis is proposed:

$\mathrm{H}_{4}$ : The Role of Village Facilitators Moderate the Effect of Village Apparatus Competence on Fraud Prevention in the management of village funds.

$\mathrm{H}_{5}$ : The Effectiveness of the Role of Village Facilitators can Moderate the Effect of Compliance with Financial Reporting on Fraud Prevention.

$\mathrm{H}_{6}$ : The Effectiveness of the Role of Village Facilitators Moderates the Effect of the Control Environment on Fraud Prevention. 


\section{RESEARCH METHOD}

The type of this study is quantitative study. The research was conducted in 109 villages in Toli-toli district. The data was analysed by using WarpPLS 7.0.

\section{RESULTS}

\subsection{Validity and Reliability}

The results of the convergent validity test show that the loading value for each indicator item is $>0.50$ which means that it meets the criteria., However, it is found that some items do not meet the requirements or have a value of more than 0.05. Discriminant validity are able to differentiate themselves from the measurement results of other concepts. Discriminant validity was assessed from the cross-loading of the measurement of constructs. The loading of latent construct will predict its indicators better than other constructs. If the construct correlation of each indicator is greater than the other construct measures, the discriminant validity is fulfilled. The results also showed that the composite reliability value for each variable had a value $>0.70$. Thus, it means that all the variables in this study meet the criteria for composite reliability.

\subsection{Inner Model Testing}

The results of the model fit test show that the average path coefficient (APC) index is 0.202 with a p-valuae value of $<0.005$ less than $<0.05$. The average $R$-squared index (ARS) is 0.697 with a p-valuae value $<0.001$, less than $<0.05$. AVIF value is $2,530<5.0$. The results showed that the criteria for testing the fit of the model in this study have been met, so that the inner model can be accepted.

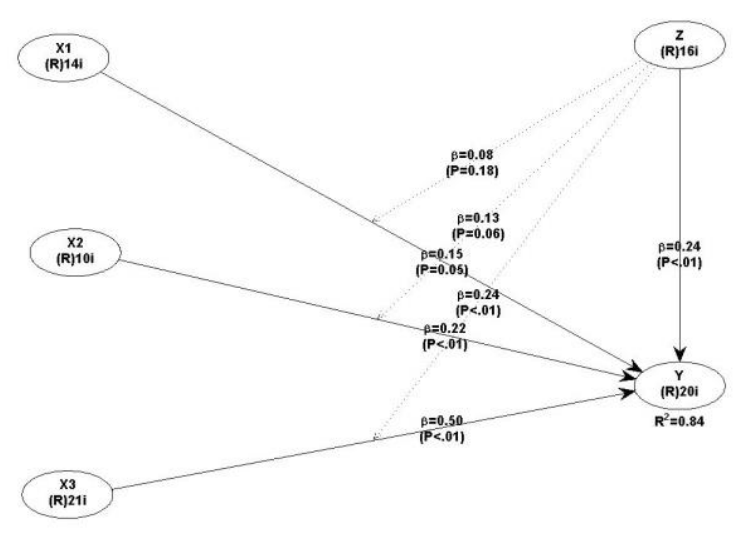

Figure 1 Research Framework

The findings of the $\mathrm{H} 1$ theory suggest that the skills of village officials have an impact on the prevention of bribery in the administration of village funds. The $\mathrm{H} 2$ hypothesis reveals a p-value of $<0.01$, which is lower than the significance level of 0.10 . The findings of the $\mathrm{H} 2$ hypothesis mean that compliance with financial statements has an effect on the fraud prevention in the village fund management. The $\mathrm{H} 3$ hypothesis reveals a $\mathrm{p}-$ value of $<0.01$, which is less than the significance level of 0.10 . The findings of the H3 hypothesis suggest that the internal environmental protection mechanism has an impact on the fraud prevention in the village funds management.

However, the results of $\mathrm{H}_{4}$ hypothesis p-value is 0.18 . This value is greater than 0.10 , which means that the predictor of the efficacy of the role of village assistants cannot moderate the relationship between the integrity of village officials and the avoidance of fraud in the administration of village funds. However, the results of hypothesis testing by looking at the indirect effect on the output of warpPLS 7.0, indicate that the p-value is 0.06 , this value is smaller than the significance rate of 0.10. Hypothesis testing shows that the variable of effectiveness of the role of village assistants can moderate the influence of compliance with financial reporting on fraud prevention of village funds in the ToliToli regency. The awareness of village assistants in their involvement in assisting village officials in reporting village development and accountability for financial reporting answers and facilitating village assistants in this case conveying amendment regulations regarding financial reporting preparation.

The results of $\mathrm{H}_{6}$ hypothesis show that the variable of effectiveness of the role of village assistants can moderate by strengthening the influence of the internal control environment on fraud prevention of in the management of village funds in the village government in Toli -Toli Regency. The test results are indicated by a p-value of $<0.01$ and the value is smaller than 0.10 . The results of the hypothesis show that the variable of effectiveness and the role of village assistants can moderate the influence of the internal control environment on fraud prevention of village funds management of Toli-Toli Regency.

\section{CONCLUSION}

This study concludes that the integrity of village administrators, compliance with financial statements and the internal environmental protection scheme has an effect on the fraud prevention in the village funds administration of the Toli-Toli district government. The effectiveness of the position of village assistants can reduce the impact of compliance with financial reporting and the internal monitoring environment for the avoidance of bribery in the distribution of village funds in Toli-Toli. The efficacy of the position of village assistants cannot, however, moderate or improve the power between the competence of village officials to deter fraud in the village funds management in the ToliToli district.

\section{AUTHORS' CONTRIBUTIONS}

All authors contribute in this research and no potential conflicts. 


\section{ACKNOWLEDGMENTS}

This publication was funded by Accounting Department of Tadulako University.

\section{REFERENCES}

[1] M. Al-Khairat, "Lilik Sugihartomno, diakses pada 25 Maret 2019 12:18.," 25 Maret 2019. [Online].

[2] R. Kassem and A. Higson, "The new fraud triangle model," Journal of Emerging Trends in Economics and Management Sciences, 2012, pp. 191-195.

[3] H. Hersi and I. Syah, "pengaruh integritas aparatur, kompetensi aparatur, dan pemanfaatan tekhnologi informasi terhadap efektivitas sistem pencegahan fraud," Jurnal Administrasi Akuntasi:Program Pascasarjana Unsyiah, 2015, pp. 55-64.

[4] K. Widiyarta, N. Herawati and A. Atmadja, "Pengaruh Kompetensi Aparatur, Budaya Organisasi, Whistleblowing Dan Sistem Pengendalian Internal Terhadap Pencegahan Fraud Dalam Pengelolaan Dana Desa (Studi Empiris Pada Pemerintah Desa Di Kabupaten Buleleng)," E-Jurnal S1 Ak Universitas Pendidikan Ganesha, 2018, pp. 25-41.

[5] P. Laksmi and I. Sujana, "Pengaruh kompetensi SDM, moralitas dan sistem pengendalian internal terhadap pencegahan fraud dalam pengelolaan keuangan desa.," E-Journal Akuntansi Universitas Udayana, 2019, pp. 2155-2182.

[6] D. Nasution, "pengaruh kualitas aparatur dan skema pengendalian internal terhadap antisipasi korupsi berjamaah dalam pelaksanaan APBD dengan integritas sebagai variabel moderating," 2019.

[7] K. Saputra, P. Pradnyanitasari, N. Priliandani and I. Putra, "Praktek Akuntabilitas Dan Kompetensi Sumber Daya Manusia Untuk Pencegahan Fraud Dalam Pengelolaan Dana Desa," 2019, pp. 168 176.

[8] E. Arfah, "Pengaruh penerapan pengendalian internal pencegahan fraud pengadaan barang dan implikasinya pada kinerja keuangan (studi pada rumah sakit pemerintah dan swasta di Kota Bandung Al-Khairat.," Jurnal Administrasi Akuntansi, 2011.

[9] D. Marsita and I. Damayanthi, "Pemoderasi pengaruh kompetensi aparatur desa dan sistem pengendalian internal pada pencegahan fraud," $E$ Journal Akuntansi Universitas Udayana, 2019, pp. 2375-2395.

[10] C. Nisak and F. Kurniawan, "Sistem pengendalian intern dalam pencegahan fraud pada satuan kerja perangkat daerah (SKPD) pada Kabupaten Bangkalan.," 2013. 